\title{
MICROBIAL DEGRADATION OF SULFENTRAZONE IN A BRAZILIAN RHODIC HAPLUDOX SOIL
}

\author{
Camila O. Martinez ${ }^{1}$, Celia Maria M. S. Silva ${ }^{2}$, Elisabeth F. Fay ${ }^{2}$, Rosangela B. Abakerli ${ }^{3}$, Aline H. N. Maia ${ }^{2}$, Lucia R. \\ Durrant ${ }^{1}$
}

${ }^{1}$ Faculdade de Engenharia de Alimentos, Universidade Estadual de Campinas, Campinas, SP, Brasil; ${ }^{2}$ Embrapa Meio Ambiente, Jaguariúna, SP, Brasil; ${ }^{3}$ Centro Pluridisciplinar de Pesquisas Químicas, Biológicas e Agrícolas, Universidade Estadual de Campinas, Campinas, SP, Brasil.

Submitted: September 26, 2008; Returned to authors for corrections: February 19, 2009; Approved: July $22,2009$.

\begin{abstract}
Sulfentrazone is amongst the most widely used herbicides for treating the main crops in the State of São Paulo, Brazil, but few studies are available on the biotransformation of this compound in Brazilian soils. Soil samples of Rhodic Hapludox soil were supplemented with sulfentrazone $(0.7 \mu \mathrm{g}$ active ingredient (a.i.) $\mathrm{g}^{-1}$ soil) and maintained at $27^{\circ} \mathrm{C}$. The soil moisture content was corrected to 30,70 or $100 \%$ water holding capacity (WHC) and maintained constant until the end of the experimental period. Herbicide-free soil samples were used as controls. Another experiment was carried out using soil samples maintained at a constant moisture content of $70 \%$ WHC, supplemented or otherwise with the herbicide, and submitted to different temperatures of 15,30 and $40^{\circ} \mathrm{C}$. In both experiments, aliquots were removed after various incubation periods for the quantitative analysis of sulfentrazone residues by gas chromatography. Herbicide-degrading microorganisms were isolated and identified. After 120 days a significant effect on herbicide degradation was observed for the factor of temperature, degradation being higher at 30 and $40^{\circ}$ C. A half-life of 91.6 days was estimated at $27^{\circ} \mathrm{C}$ and $70 \%$ WHC. The soil moisture content did not significantly affect sulfentrazone degradation and the microorganisms identified as potential sulfentrazone degraders were Nocardia brasiliensis and Penicillium sp. The present study enhanced the prospects for future studies on the bio-prospecting for microbial populations related to the degradation of sulfentrazone, and may also contribute to the development of strategies for the bioremediation of sulfentrazone-polluted soils.
\end{abstract}

Key words: herbicide, degradation, microorganisms, half-life

\section{INTRODUCTION}

Herbicides deserve special attention since their dissipation, persistence and transformation indicate their effectiveness as products and their potential danger to the microbiota and to the quality of the environment. The herbicide sulfentrazone $[\mathrm{N}$ - [2,4-dichloro-5-[4-(difluoromethyl)-4,5-dihydro- 3-methyl-5oxo-1H-1,2,4-triazol-1-y1] phenyl] methanesulfonamide] is one of the most widely used in soybean and sugarcane crops in the State of São Paulo, which is the second largest producer of both these crops in Brazil $(11,14)$.

\footnotetext{
*Corresponding Author. Mailing address: Embrapa Environment, Rodovia SP 340 - Km 127.5, Caixa Postal 69, Jaguariúna. SP. Brazil. CEP: 13820-000.; Tel.: (19) 3311-2637.; Email: bethfay@cnpma.embrapa.br
} 
Sulfentrazone is stable in the soil, with a half-life $\left(\mathrm{DT}_{50}\right)$ of 121 days in sandy soils and 302 days in clay soils (7). Besides being highly persistent, it is highly mobile (mean partitioning coefficient, $\mathrm{K}_{\mathrm{oc}}=43$; mean sorption coefficient, $\mathrm{K}_{\mathrm{d}}$ $<1$ ), and shows good vertical (to ground water) and horizontal leaching potentials (10). In addition to the water contamination problem, the microbial diversity could be intensely affected by the continued use of this herbicide (17), although it can be mineralized by microorganisms. Its availability to soil microorganisms depends on temperature and moisture factors, since both affect its adsorption to the soil, influencing its bioactivity and persistence (6).

There is a lack of studies characterizing the environmental fate of sulfentrazone under a range of conditions likely to be encountered in Brazil. In environments with tropical climates, weathering is favored by conditions of high temperature and precipitation associated with good drainage, resulting in the formation of soils with a 1:1 accumulation clay minerals and iron and aluminum oxides (31). In Brazil, the oxisols comprise about 50 to $60 \%$ of all the land (26).

Thus, the objective of this study was to determine the effects of temperature and moisture on the dissipation of sulfentrazone under controlled laboratory conditions, with particular attention to the isolation and identification of potentially degradation microorganisms.

\section{MATERIALS AND METHODS}

The biotransformation of sulfentrazone was evaluated in Rhodic Hapludox soil samples (40), a class of oxisols. The investigation consisted of two separate laboratory soil incubations. The first incubation experiment tested the effects of moisture variations and the second, the effects of temperature variations on the biotransformation of sulfentrazone, using the product concentration recommended for field use in both tests. For this study, the soil samples were collected from areas that had no previous register of sulfentrazone application. The soil studied presented the following chemical and physical characteristics: $\mathrm{pH}$ in water
5.01 ; organic matter $21 \mathrm{~g} \mathrm{dm}^{-3}$; potential acidity $88 \mathrm{mmol}_{\mathrm{c}} \mathrm{dm}^{-}$ ${ }^{3}$; aluminium $19 \mathrm{mmol}_{\mathrm{c}} \mathrm{dm}^{-3}$; iron $83 \mathrm{mmol}_{\mathrm{c}} \mathrm{dm}^{-3}$; clay $37.3 \%$; silt $16.2 \%$; total sand $46.6 \%$; textural classification Loamy.

\section{Soils and treatments}

Effect of moisture variations: Ten soil subsamples were collected at random from a depth of $0-10 \mathrm{~cm}$. In the laboratory the subsamples were mixed and homogenized to form a composite sample, and then air-dried, sieved ( $2 \mathrm{~mm}$ mesh) and refrigerated at $4^{\circ} \mathrm{C}$ before the incubation tests. The soil $\mathrm{pH}$, residual moisture content and water holding capacity (WHC) were determined according to the methods proposed by Embrapa (9). One hundred and fifty grams of the composite soil sample were transferred to $500 \mathrm{ml}$ Erlenmeyer flasks and corrected for the humidity to give 30, 70 and $100 \%$ WHC, and maintained at $27^{\circ} \mathrm{C}$ for seven days before adding the herbicide. At the end of this period, technical grade sulfentrazone (92\% purity, FMC Corporation) was applied by mixing an aqueous suspension into the experimental units at the same soil concentration rate used in the field $\left(0.7 \mu \mathrm{g} \mathrm{g}^{-1}\right.$ soil $)$, and maintaining the desired soil moisture levels. Soil samples without the addition of herbicide were used as the controls. Three replicate flasks were used for each treatment. Soil samples were taken 14, 30, 60, 120, 180 and 255 days after treatment, and evaluated using gas chromatography to determine the amount of herbicide degraded.

Effect of temperature variations: another experiment was carried out using soil samples with $\left(0.7 \mu \mathrm{g} \mathrm{g}^{-1}\right.$ soil $)$ and without the addition of herbicide, all corrected for soil moisture content at the $70 \%$ WHC level and incubated at three different temperatures: 15,30 and $40^{\circ} \mathrm{C}$. Three replicates were made for each treatment. The residues of sulfentrazone were quantified by gas chromatography after 14, 30, 60 and 120 days of incubation.

\section{Extraction and analysis of residual sulfentrazone and} its metabolites from the soil samples: The extraction of sulfentrazone from soil (10 g) was carried out using a mixture of acetone- $\mathrm{HCl} 0.25 \mathrm{~mol} \mathrm{~L}^{-1}$ solutions, under reflux of 1 hour, followed of filtration and concentration in a rotary evaporator 
at $40^{\circ} \mathrm{C}$. Three replicate flasks were used for each treatment. The sample cleanup and sulfentrazone enrichment was carried out in solid phase cartridges of $\mathrm{C} 8$ and silica gel. The sulfentrazone identification and quantification were made by gas chromatography and electron capture detention in a column DB $608(30 \mathrm{~m} \times 0,53 \mathrm{~mm} \times 0.83 \mu \mathrm{m})$. The detection limit (LOD) was fixed at $0.01 \mu \mathrm{g} \mathrm{mL}^{-1}$ and the limit of quantification (LOQ) was $0.05 \mathrm{mg} \mathrm{kg}^{-1}$. The validation in the soil was carried out at the spiked level of $0.05 \mathrm{mg} \mathrm{kg}^{-1}$. The efficiency of the applied method was evaluated as function of recovery of the pesticide in fortified samples. All the recoveries were within the acceptability range of 70 and $120 \%$.

The metabolite 3-hydroxymethylsulfentrazone (HMS) was identified by high performance liquid chromatography (HPLC $)^{7}$. The chromatographic conditions were as follows: Shimadzu chromatograph, C18 reverse-phase column, flow of

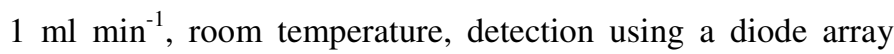
detector (DAD), UV 254nm, 24:75 to 60:40 gradient in 60 minutes, with the mobile phase consisting of $0.5 \%$ acetonitrile and acetic acid.

Isolation and characterization of sulfentrazonedegraders: the enriched soils $(10 \mathrm{~g})$ with and without the addition of sulfentrazone, incubated for 120 days at $27^{\circ} \mathrm{C}$ and $70 \%$ WHC, were aseptically suspended in $90 \mathrm{ml}$ of distilled water for two minutes using a Vortex mixer. Serial dilutions of the suspensions $\left(10^{-2} ; 10^{-3}\right.$ and $\left.10^{-4}\right)$ were transferred to a minimal medium $\left(\mathrm{NaNO}_{3} 3 \mathrm{~g} ; \mathrm{K}_{2} \mathrm{HPO}_{4} 1 \mathrm{~g} ; \mathrm{MgSO}_{4} .7 \mathrm{H}_{2} \mathrm{O} 0.5\right.$ g; $\mathrm{KCl} 0.5 \mathrm{~g}$; $\mathrm{FeSO}_{4} .7 \mathrm{H}_{2} \mathrm{O} 0.01 \mathrm{~g}$; agar $16 \mathrm{~g} ; \mathrm{H}_{2} \mathrm{O} 1000 \mathrm{ml}$ ) with sulfentrazone $\left(0.7 \mu \mathrm{g}\right.$ i.a ml ${ }^{-1}$ medium $)$ added as the sole carbon and energy source. Herbicide-free medium was used as the control. After incubation for $2 ; 7$ and 17 days at $27^{\circ} \mathrm{C}$, the individual colonies of bacteria, actinomycetes and fungi grown in the medium were respectively picked and transferred to new minimum liquid medium $(99 \mathrm{ml})$. After serial dilution, $1 \mathrm{ml}-$ aliquots of the $10^{-1}$ dilution were inoculated into Erlenmeyer flasks containing $99 \mathrm{ml}$ of the same medium plus the herbicide at different concentrations $\left(2.1 ; 4.2\right.$ and $7.0 \mu \mathrm{g}$ i.a $\mathrm{ml}^{-1}$ medium). The cultures were transferred three times over a fifty day period. The microorganisms were isolated after vortexing in a $0.1 \%$ Tween 80 solution and streaking on solid medium. The selected strains were then purified in a medium containing sulfentrazone ( $7.0 \mu \mathrm{g}$ i.a ml ${ }^{-1}$; ten-fold the field rate) as the sole carbon source.

The effect of the herbicide on the soil culturable microbiota $(<10 \%$ of real environmental indigenous microbiota), measured by the number of colony-forming units (CFU), was evaluated by comparing the mean number of CFUs in soil samples with or without sulfentrazone, using Student's test with Satterthwaite's approximation (30). The TTEST Procedure of the SAS System (28) was used. It is now generally accepted that even more than $99 \%$ of microbes are unculturable with the commonly established methods (38).

The isolated bacterial and actinomycetes strains were identified by an analysis of their fatty acid-methyl esters (FAMEs) using the Microbial Identification System developed by Microbial ID (21). Cell fatty acids were extracted according to Sasser (29). Fatty acid methyl-esters from each strain were separated using a Hewlett-Packard gas chromatography model fitted with a fused silica column $(25 \mathrm{~m} \times 0.2 \mathrm{~mm}$ internal diameter). FAME peaks were named by the MISsoftware, and bacterial strains were identified using the MIS "Aerobia Library" (Version TSBA50).

The fungal stock cultures were maintained at $4^{\circ} \mathrm{C}$ on Sabourad medium (39). The procedure for the strain identification was adapted from Nogueira and Barroso (24) for visualization; and the images were obtained by scanning electron microscopy and identified with the help of a specific manual (4).

Statistical analysis: The influence of moisture and incubation period on the remaining amount of sulfentrazone (RASulf) was investigated using variance analysis and Snedecor's F tests (22). The same analysis was performed to evaluate the effect of temperature on RASulf. The influence of temperature and moisture on the mean degradation rate was quantified by RASulf on the last evaluation date, since the initial amount $\left(0.7 \mu \mathrm{g} \mathrm{g}^{-1}\right)$ was constant for all treatments. To accomplish this, $\mathrm{t}$ tests were performed for contrasts between the RASulf recorded means at different temperature and 
moisture levels. Analysis of variance and t tests for contrasts were performed using the MIXED Procedure of the SAS System (28). Where significant differences between RASulf means arose for any of the contrasts evaluated, we selected the factor level (temperature or moisture) with the lowest RASulf (highest degradation rate) to fit degradation models and to estimate half-life values (in cases where RASulf was lower than $50 \%$ on the last evaluation date). Nonlinear, negative exponential type models were fitted (Equation 1).

\section{$\operatorname{RASulf}(t)=1$ - a.exp $(-\mathrm{b} . t)+\mathrm{e} ; \mathrm{a}>0 ; \mathrm{b}>0$}

(Equation 1)

Where RASulf $(t)$ is the fraction of sulfentrazone remaining in time $t$, a is the maximum degradation attained, $\mathrm{b}$ is the parameter related to the degradation velocity in the descending phase, and $\mathrm{e}$ is the random error associated with each observation. The half-life corresponds to the $t$ value for which the predicted RASulf $(\mathrm{t})$ value is equal to 0.50 . The Gauss-Newton method (3), implemented in the SAS System's NLIN Proc (28) was used to fit the models. The above negative exponential model is adequate for describing degradation process for which the velocity of degradation is not constant over time. At time zero, the remaining fraction (RASulf(t)) is equal to one; according to the proposed model, the fraction RASulf(t) decreases asymptotically to zero, which is consistent with the process being modeled.

\section{RESULTS}

The factor of moisture had no significant effect on sulfentrazone degradation (t test for contrasts; $P>0.30$ ). At $100 \%$ of WHC, no degradation of the herbicide was verified for up to 255 days of incubation. At 30 to $70 \%$ of WHC, degradation was similar to the highest degradation value, reaching $41 \%$ (RASulf $=0.41 \mu \mathrm{g} \mathrm{g}^{-1}$ ) after 255 days of incubation at $30 \% \mathrm{WHC}$ and $36 \%$ at $70 \% \mathrm{WHC}$ in the same period.

There was an effect of temperature on sulfentrazone degradation (F test, $P<0.0005$ ). Herbicide degradation was higher at temperatures of 30 and $40^{\circ} \mathrm{C}$ and there was no difference between the two (Table 1), an increase in the degradation rate being observed after 60 days for all treatments. According to the data observed, the highest degradation was $63.2 \%\left(Q R S u l f=0.26 \mu \mathrm{g} \mathrm{g}^{-1}\right)$ followed by $56.7 \%$, after 120 days of incubation at $40^{\circ} \mathrm{C}$ and $30{ }^{\circ} \mathrm{C}$ respectively. The half-life estimate for sulfentrazone was 91.6 days in the treatment that provided the greatest sulfentrazone degradation $\left(40^{\circ} \mathrm{C}\right.$ and $\left.70 \% \mathrm{WHC}\right)$. Figure 1 shows the fitted degradation curve and the estimates for the parameters $\alpha$ and $\beta$ of the corresponding model were 1.3456 (s.e. $=1.49$ ) and 0.0051 (s.e. $=0.007)$, respectively.

Table 1. Mean values for the remaining amount of sulfentrazone ( $\mu \mathrm{g} \mathrm{g}^{-1}$ ) in a Rhodic Hapludox soil with time, under different temperature levels $\left({ }^{\circ} \mathrm{C}\right)$.

\begin{tabular}{ccccc}
\hline & \multicolumn{5}{c}{ Mean values for the remaining amount of sulfentrazone $\left(\boldsymbol{\mu g} \mathbf{~ g}^{-1}\right)$} \\
\cline { 2 - 5 } & \multicolumn{1}{c}{$\mathbf{0} \mathbf{C}$} & $\mathbf{1 4}$ & $\mathbf{3 0}$ & $\mathbf{1 2 0}$ \\
\cline { 2 - 5 } & 0.70 & 0.79 & 0.56 & 0.44 \\
\hline 15 & 0.70 & 0.61 & 0.46 & 0.30 \\
40 & 0.70 & 0.55 & 0.55 & 0.26 \\
\hline
\end{tabular}


Temperature $=40^{\circ} \mathrm{C}$

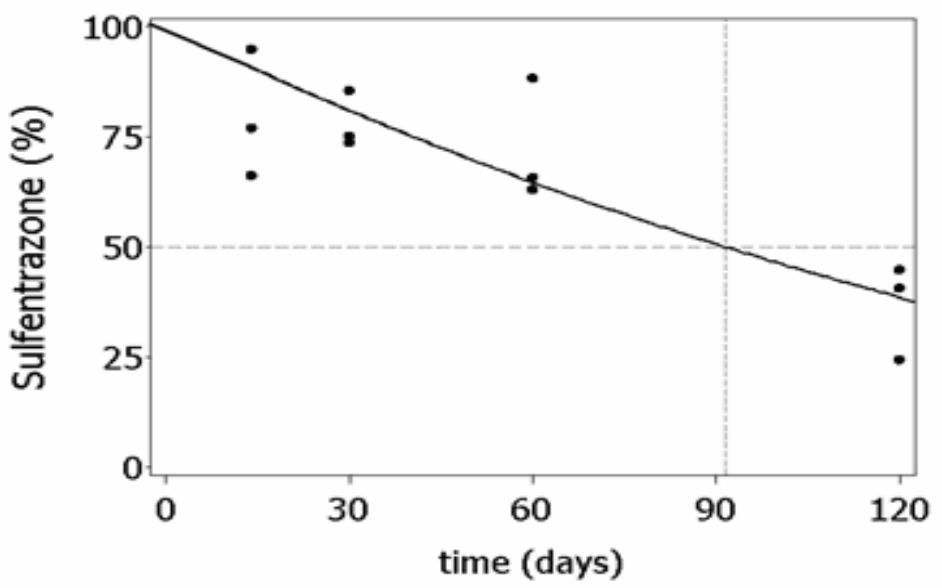

Figure 1. Sulfentrazone degradation in a Rhodic Hapludox soil with time at $40^{\circ} \mathrm{C}$ and $70 \%$ WHC. The dotted vertical line indicates the half-life value: 91.6 days (— fitted negative exponential model, $\bullet$ observed values).

The presence of the metabolite 3-hydroxymethyl sulfentrazone (HMS) in the soil samples incubated at $30^{\circ} \mathrm{C}$ and $70 \%$ WHC was observed, coinciding with the disappearance of the parental compound. Although, the analyses to detect the parent compounds and metabolites were done on all the sampling dates, the presence of the metabolite 3hydroxymethyl sulfentrazone (HMS) was only observed under these conditions.

It was observed that bacterial growth was inhibited by the presence of the herbicide: there was a mean reduction of 400 thousand CFUs in relation to the control (t test, $P=0.0140$ ). However the growth of fungi and actinomycetes was favored by the presence of the herbicide, observing increases of 98 and 290 thousand CFUs, respectively (Table 2). The bacterial strain Nocardia brasiliensis GC subgroup B was selected as a potential sulfentrazone degrader (tolerant to a rate of $4.2 \mu \mathrm{g} \mathrm{ml}^{-}$ ${ }^{1}$ ), with a similarity index of 0.614 obtained by means of comparison against the TSBA 40 library database (Table 3). Taking into consideration the greater herbicide concentration used, the selection made by the herbicide permitted the identification of these strains as possible herbicide degraders. Penicillium sp. was the only fungal strain isolated as a possible sulfentrazone degrader in a culture medium with sulfentrazone as the only carbon and energy source.

Table 2. Evaluation of the effect of the herbicide sulfentrazone on the mean number of microbial colony-forming units isolated in a Rhodic Hapludox soil. Application of Student's t Test.

\begin{tabular}{lccccc}
\hline Organisms & $\begin{array}{c}\text { Sulfentrazone } \\
\left(\mathbf{0 . 7} \boldsymbol{\mu g} \mathbf{~ g}^{-\mathbf{1}}\right)\end{array}$ & $\begin{array}{c}\mathbf{M}^{\mathbf{M}} \\
(\mathbf{C F U})\end{array}$ & Lower limit $^{\mathbf{b}}$ & Upper limit $^{\mathbf{b}}$ & $\boldsymbol{p}_{\text {value }}$ \\
\hline Actinomycete & Absent & 233.33 & 175.965 & 290.70 & \\
Actinomycete & Present & 523.33 & 312.060 & 734.61 & \\
Actinomycete & Difference & 290.00 & & & 0.02135 \\
Bacterium & Absent & 433.33 & 225.001 & 641.67 & \\
Bacterium & Present & 33.33 & 18.991 & 47.68 & \\
Bacterium & Difference & -400.00 & & & 0.01401 \\
Fungi & Absent & 11.33 & -19.327 & 41.99 & \\
Fungi & Present & 109.33 & 77.295 & 141.37 & \\
Fungi & Difference & 98.00 & & & 0.00069 \\
\hline
\end{tabular}

a) Difference between numbers of CFU in samples with or without sulfentrazone.

b) Value 1,000 times smaller than the observed (divided by 1,000).

c) $p$ value relative to the $\mathrm{t}$ test. 
Table 3. Identification of bacterial strains using MIS, in a Rhodic Hapludox Soil. These microorganisms were isolated in a medium supplemented with sulfentrazone in different concentrations, as a sole carbon and energy source.

\begin{tabular}{|c|c|c|c|}
\hline $\begin{array}{c}\text { Soil/ } \\
\text { Isolate } \mathbf{n}^{\circ}\end{array}$ & Sulfentrazone $\left(\mu \mathrm{g} \mathrm{ml}^{-1}\right)$ & Identification of single colonies & $\begin{array}{c}\text { Library } \\
\text { Matches* }\end{array}$ \\
\hline RHS 9 & 2.13 & Nocardia pseudobrasiliensis & 0.521 \\
\hline RHS 3 & 2.13 & Nocardia brasiliensis GC, subgroup B & 0.481 \\
\hline RHS 4 & 2.13 & Rhodococcus rhodnii & 0.283 \\
\hline \multirow[t]{2}{*}{ RHS 1} & 4.22 & Nocardia nova ou Nocardia brasiliensis GC, & $0.634 /$ \\
\hline & & subgrupo B & 0.614 \\
\hline RHS 8 & 2.13 & Nocardia brasiliensis GC, subgroup B & 0.546 \\
\hline RHS 6 & 2.13 & Nocardia brasiliensis GC, subgroup B & 0.521 \\
\hline RHS 2B & 4.22 & Nocardia brasiliensis GC, subgroup B & 0.526 \\
\hline RHS 7 & 2.13 & Nocardia brasiliensis GC, subgroup B & 0.497 \\
\hline RHS 2 & 4.22 & Gordonia-amarae GC subgroup B & 0.497 \\
\hline RHS 5 & 2.13 & Nocardia brasiliensis GC, subgroup B & 0.378 \\
\hline
\end{tabular}

*Library matches are expressed on a scale of 0 to 1 , with a match of 0.6 or greater considered good to the species level.

\section{DISCUSSION}

The dissipation of sulfentrazone is an important aspect to be exploited, due to its characteristics and the contamination potential of the herbicide $(1,10)$. According to Hatzios (16), the primary method for the dissipation of sulfentrazone in soil is considered to be microbial degradation, and the reported half-life $\left(\mathrm{DT}_{50}\right)$ is from 110 to 280 days depending on the soil and environmental conditions.

Researchers have demonstrated that the rate of herbicide degradation can be strongly influenced by the soil moisture content and temperature, due to interference of these parameters on the soil microorganisms $(18,27,36,43)$. Weber \& Weed (45) reported that higher soil temperatures and moisture contents enhanced the degradation of triazine, and degradation has been reported to be faster in moist soil than in dry soil (44). Soil moisture content was the more critical parameter with respect to herbicides that required microbes to degrade them (34), and soil microbes thrive in warm, moist soils, resulting in faster degradation (12).

With respect to the moisture content, in the present research carried out under laboratory conditions, sulfentrazone degradation was approximately $40 \%$ up to 225 days at 30 and $70 \%$ WHC. However there was no degradation at $100 \%$ WHC where anaerobic microorganisms, both obligatory and facultative, predominate, indicating that sulfentrazone degradation occurs specifically by aerobic organisms. The mechanism of degradation in aerobic soil has not been reported, but some data are available on the effects of soil type, and the results obtained in other Brazilian soils have confirmed the above affirmation (20).

Sulfentrazone dissipation was not significantly affected by variations in soil moisture content, but increased with increasing temperature. The degradation rates of the herbicide at 30 and $40^{\circ} \mathrm{C}$ were similar. The results presented here show that the half-life of sulfentrazone decreased with increasing temperature at the moisture level tested. Its half-life was 91.6 days at $40^{\circ} \mathrm{C}$ and $70 \%$ WHC, a temperature higher than the values found under natural field conditions in temperate climates.

Increased degradation rates of many herbicides with increase in temperature have been confirmed in field studies 
(27). The results suggest that the $\mathrm{DT}_{50}$ value for sulfentrazone in the surface of tropical soils may be shorter than previously reported in the Herbicide Handbook (42). In this paper, the changes found in the composition of the microbial community and other soil properties as a result of handling under laboratory conditions, cannot be considered as equivalent to those occurring under real field conditions, where the influence of soil structure on the soil microbiota affects herbicide degradation. Furthermore, the resistance of soil microorganisms to soil drying and rewetting is influenced by their metabolic activity, which is determined by their type and physiological state. Other soil-related factors are not excluded, but appear to be of only minor importance.

The sources of degradation after drying and rewetting are organic substrates derived from microorganisms killed by the drying process and, to a larger extent, from other non-living soil organic matter. The contribution of the non-biomass soil organic carbon to the mineralization flush after soil drying and remoistening is largely dependent on the localization of the microorganisms in the soil structure relative to their substrates $(13,41)$.

Despite favorable conditions for microbial activity in soils, the biodegradation of herbicides may be hampered due to their poor bioavailability as result of limitations in mass transfer via processes of sorption, desorption or dissolution.

The adsorption of sulfentrazone increases with increasing soil acidity (15). The soil under study showed a low $\mathrm{pH}$ value, below the $\mathrm{pKa}$ value of the herbicide (6.56), and thus it appears that the molecule was in its neutral form, in which solubility is reduced (37), increasing adsorption. The contribution of the $\mathrm{Fe}$ and $\mathrm{Al}$ oxides and hydroxides was quite important, because the surface charge depends on the $\mathrm{pH}$, and adsorption is an outcome of ionic bonding between the minerals and the acid grouping of the molecule at low $\mathrm{pH}$ values (2). The soil moisture content did not significantly affect the microbial activity in this study, but could alter the distribution of the sulfentrazone between the solution and the sorbed phases.

Since the soil under study had had no previous contact with the herbicide, an adjustment phase (lag phase) of the microorganisms to the compound was observed, the duration varying according to the treatment. Soil supplementation with sulfentrazone can introduce a selective process amongst the natural populations, which favors the growth of adapted strains that can survive in the presence of the contaminant, while less specialized ones tend to disappear.

After the lag period, the microorganisms were capable of degrading the herbicide, as corroborated by the presence of the metabolite 3-hydroxymethyl sulfentrazone, which is known to be less toxic than sulfentrazone (8). Besides being less toxic, the metabolite is more polar and more mobile in the soil environment than the parent compound. This shows that, despite the lack of information in the literature about the microbial degradation route of sulfentrazone, the disappearance of the parent compound coinciding with the appearance of the metabolite at the end of the experimental period was in accordance with the metabolism of the herbicide in plants and animals (19). Thus HMS was shown to be one of the components in the metabolic degradation route of this herbicide by microorganisms in soil. Ohmes et al. (25) showed that microbial degradation is an important mechanism for sulfentrazone dissipation, since its degradation was very low in autoclaved soils.

With regard to the effect of sulfentrazone on the soil microflora, the molecule reduced the growth of the culturable bacterial community. Due the adaptation period, even though culturable bacterial counts may drop, degradation of the herbicide may be enhanced due to the imposed selection. However, highly adapted strains are less likely to grow on culture media in the laboratory, which can explain the CFU reduction observed, even though the pesticide was being degraded. Furthermore, this reduction could have been the result of stimulation of culturable fungal growth by the herbicide, which is also influenced by the acidic $\mathrm{pH}$ of the soil.

Despite the lack of references about potential sulfentrazone degraders, in this paper the microorganisms isolated as potential sulfentrazone degraders were Nocardia brasiliensis and Penicillium sp. Studies exist about the influence of isolated microorganisms on the degradation of 
other organic compounds $(5,18,23,32,33,35)$.

\section{CONCLUSION}

The results presented here showed that the dissipation of sulfentrazone was primarily a biological process and indicated its dependence on the temperature, which suggests that the $\mathrm{DT}_{50}$ value for sulfentrazone in the surface of tropical soils may be shorter than previously thought, although the present data were obtained from laboratory incubations. The present study enhanced the prospects for future studies on the bioprospecting for microbial populations related to the degradation of sulfentrazone, and may also contribute to the future development of strategies for the bioremediation of sulfentrazone-polluted soils.

\section{ACKNOWLEDGMENTS}

Financial support for this project was provided by The State of São Paulo Research Foundation (Fundação de Amparo à Pesquisa do Estado de São Paulo - (FAPESP). We would also like to thank to two anonymous reviewers for their valuable advice and constructive criticism which greatly improved the manuscript.

\section{REFERENCES}

1. Agrofit. (2004).

Available at: http://extranet.agricultura.gov.br/agrofit_cons/principal_agrofit_cons. Acessed 9 set 2008.

2. Alves, P.L.C.A.; Marques Jr, J.; Ferraudo, A.S. (2004). Soil attributes and the efficiency of sulfentrazone on control of purple nutsedge (Cyperus rotundus L.). Sci. Agric. 61 (3), 319-325.

3. Bard, J. (1970). Comparison of gradient methods for the solution of the nonlinear parameter estimation problem. SIAM J. Numer. Anal. 7 (1), $157-186$.

4. Barnett, H.L.; Hunter, B.B. (1972). Illustrated Genera of Imperfect Fungi. Burgess Publishing, Minneapolis.

5. Benezet, H.J.; Knowles, C.O. (1982). Microbial degradation of thidiazuron and its photoproduct. Arch. Environ. Contam. Toxicol. 11 (1), 107-110.

6. Beulke, S.; Brown, C.D.; Fryer, C.J.; Van Beinum, W. (2004). Influence of kinetic sorption and diffusion on pesticide movement through aggregated soils. Chemosphere 57 (6), 481-490.
7. Chen, A. (2003). Sulfentrazone. In: Lee, P.W. (ed). Handbook of Residue Analytical Methods for Agrochemicals, vol. 1. John Wiley, Chichester, p.564-577.

8. Dayan, F.E.; Armstrong, B.M.; Weete, J.D. (1998). Inhibitory activity of sulfentrazone and its metabolic derivatives on soybean (Glycine max) protoporphyrinogen oxidase. J. Agric. Food Chem, 46 (5), 2024-2029.

9. Embrapa. Centro Nacional de Pesquisa de Solos. (1997). Manual de Métodos de Análise de Solo. Embrapa-CNPS, Rio de Janeiro.

10. EPA. (2003). Federal register: Sulfentrazone; pesticide tolerances. Available at: $\quad$ http://www.epa.gov/fedrgstr/EPAPEST/2003/September/Day-4/p24011.htm. Acessed 16 set. 2008.

11. Fairbanks, M. (2005). Defensivos agrícolas ampliam mercado. Available at: http://www.quimica.com.br/revista/qd396/defensivos_agricolas.htm. Acessed 16 set. 2008.

12. Fay, E.F.; Silva, C.M.M.S. (2004). Persistência de moléculas xenobióticas. In: Silva, C.M.M.S., Fay, E. F. (eds). Agrotóxicos \& Ambiente. Embrapa Informação Tecnológica, Brasília, DF, p. 221-257.

13. Gordon, H.; Haygarth, P.M.; Bardeett, R.D. (2008). Drying and rewetting effects on soil microbial community composition and nutrient leaching. Soil Biol. Biochem. 40, 302-311.

14. Governo do Estado de São Paulo. (2005). Agricultura. Available at: http://www.saopaulo.sp.gov.br/invista/numeros/agric.htm. Acessed 15 maio 2005.

15. Grey, T.L.; Walker, R.H.; Hancock, H.G. (1997). Sulfentrazone adsorption and mobility affected by soil and pH. Weed Sci. 45 (5), 733738.

16. Hatzios, K.K. (1998). Supplement to Herbicide Handbook. 7th ed. Weed Science Society of America, Lawrence, p. 67-69.

17. Johnsen, K.; Jacobsen, C.S.; Torsvik, V.; Sorensen, J. (2001). Pesticide effects on bacterial diversity in agricultural soils - a review. Biol. Fert. Soils 33 (6), 443-453.

18. Kodama, T.; Ding, L.; Yoshida, M.; Yajima, M. (2001). Biodegradation of an s-triazine herbicide, simazine. J. Mol. Catal. B Enzym. 11 (4-6), 1073-1078.

19. Martinez, C.O.; Silva, C.M.M.S.; Fay, E.F.; Abakerli, R.B.; Maia, A.H.N.; Durrant, L.R. (2008). The effects of moisture and temperature on the degradation of sulfentrazone. Geoderma 147, 56-62.

20. Martinez, C.O. (2006). Biotransformação do herbicida sulfentrazona em solos brasileiros. Campinas, Brasil, 109p. (M.Sc. Dissertation. Universidade Estadual de Campinas).

21. MIDI. (2001). Microbial Identification System Operating Manual. MIDI, Inc., Newark.

22. Montgomery, D.C. (1991). Design and Analysis of Experiments. John Wiley, New York.

23. Mulbry, W.W.; Zhu, H.; Nour, S.M.; Topp, E. (2002). The triazine hydrolase gene atzN from Nocardioides sp. strain C190: cloning and construction of gene-specifc primers. FEMS Microbiol. Lett. 206 (1), 7579. 
24. Nogueira, N.L.; Barroso, P.A.V. (1998). Microscopia eletrônica aplicada aos estudos de ecologia microbiana. In: Melo, I.S., Azevedo, J.L. (eds). Ecologia Microbiana. Embrapa-CNPMA, Jaguariúna, p. 279-307.

25. Ohmes, G.A.; Hayes, R.M.; Mueller, T.C. (2000). Sulfentrazone dissipation in a Tennessee soil. Weed Technol. 14, 100-105.

26. Regitano, J.B.; Alleoni, L.R.F.; Tornisielo, V.L. (2001). Atributos de solos tropicais e a sorção de imazaquin. Sci. Agric. 58, 801-807.

27. Sahid, I.B.; Teoh, S.S. (1994). Persistence of terbuthylazine in soils. Bull. Environ. Contam. Toxicol. 52 (2), 226-230.

28. SAS Institute. (2004). SAS/STAT 9.1 users guide. SAS Institute Inc, Cary, NC.

29. Sasser, M. (1990). Identification of Bacteria by Gas Chromatography of Cellular Fatty Acids. Microbial ID, Inc., Newark.

30. Satterthwaite, F.W. (1946). An approximate distribution of estimates of variance components. Biometrics Bul.l 2 (6), 110-114.

31. Silva, A.A.; Oliveira Junior, R.S.; Castro Filho, J.E. (1998). Avaliação da atividade residual no solo de imazaquin e trifuralin através de bioensaios com milho. Acta Sci. 20, 291-295.

32. Silva, T.M.; Stets, M.I.; Mazzetto, A.M.; Andrade, F.D.; Pileggi, S.A.V.; Fávero, P.R.; Cantú, M.D.; Carrilho, E.; Carneiro, P.I.B.; Marcos Pileggi, M. (2007). Degradation of 2,4-d herbicide by microorganisms isolated from brazilian contaminated soil. Braz. J. Microbiol. 38, 522-525.

33. Smith, D.; Alvey, S.; Crowley, D.E. (2005). Cooperative catabolic pathways within an atrazine-degrading enrichment culture isolated from soil. FEMS Microbiol. Ecol. 53 (2), 265-273.

34. Strek, H.J. (2005). The science of Dupont's soil residual herbicides in Canada. In: van Acker, R.C. (ed). Soil Residual Herbicides: Science and Management. Canadian Weed Science Society, Quebec, p.31-44. (Topics in Canadian Weed Science, v.3).

35. Strzelec, A. (1975). The influence of glucose on simazine decomposition.
Acta Microbiol. Pol. Ser B Microbiol. Appl. 7 (2), 91-96.

36. Taylor-Lovell, S.; Sims, G.H.; Wax, L.M. (2002). Effects of moisture, temperature, and biological activity on the degradation of isoxaflutole in soil. J. Agric. Food Chem. 50 (20), 5626-5633.

37. Tomlin, C.D.S. (2000). The Pesticide Manual: a world compendium. British Crop Protection Council, Croydon, UK.

38. Torsvik, V.; Goksoyr, J.; Daae, F.L. (1990). High diversity in DNA of soil bacteria. Appl. Environ. Microbiol. 56, 782-787.

39. Tuite, J. (1969). Plant Pathology Methods: fungi and bacteria. Burgess, Minneapolis.

40. USDA Soil Conservation Service, Soil Survey Staff. (1975). Soil Taxonomy: a basic system of soil classification for making and interpreting soil surveys. U.S. Government Printing Office, Washington, DC.

41. Van Gestel M.; Merckx, R.; Vlassak, K. (1993). Microbial biomass responses to soil drying and rewetting: The fate of fast- and slowgrowing microorganisms in soils from different climates. Soil Biol. Biochem. 25, 109-123.

42. Vencill, W.K. (2002). Herbicide Handbook. 8th ed. Weed Science Society of America, Lawrence.

43. Walker, A.; Moon, Y.H.; Welch, S.J. (1992). Influence of temperature, soil moisture and soil characteristics on the persistence of alachlor. Pestic. Sci. 35 (2), 109-116.

44. Walker, A.; Zimdahl, R.L. (1981). Simulation of the persistence of atrazine, linuron and metolachlor in soil at different sites in the USA. Weed Res. 21, 255-265.

45. Weber, J.B.; Weed, S.B. (1974). Effects of soil on the biological activity of pesticides. In: Guenzi, W.D. (ed). Pesticides in Soil and Water. Soil Science Society of America, Madison, p.223-226. 